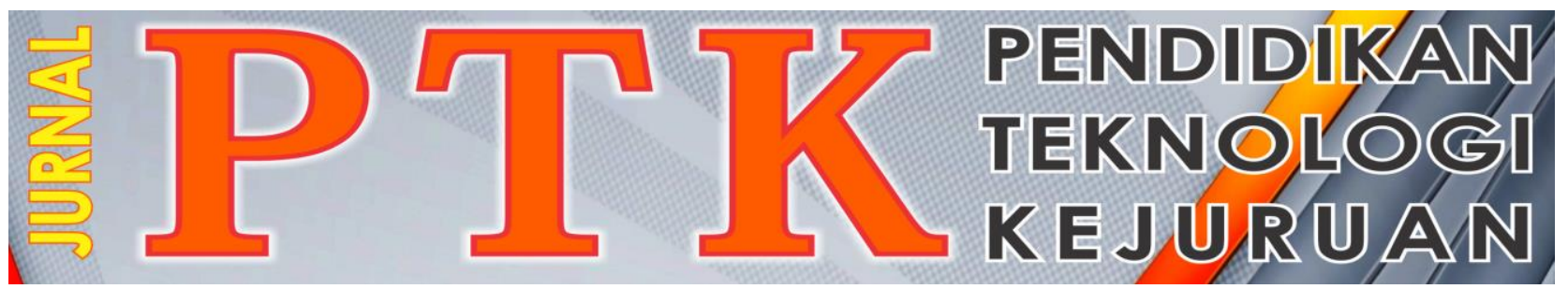

Vol. 3, No. 2 Mei 2020

P-ISSN: 2621-3273

E-ISSN: 2621-1548

\title{
THE DEVELOPMENT OF POWER ELECTRONICS TRAINING KITS FOR ELECTRICAL ENGINEERING STUDENTS: A VALIDITY TEST ANALYSIS
}

\author{
Citra Dewi ${ }^{1}$, Doni Tri Putra Yanto ${ }^{2 *}$, dan Hastuti ${ }^{3}$ \\ ${ }^{123}$ Jurusan Teknik Elektro, Fakultas Teknik, Universitas Negeri Padang \\ *Corresponding author, e-mail: donitriputra@ft.unp.ac.id ${ }^{2}$
}

\begin{abstract}
Abstrak - Penelitian ini membahas tentang salah satu tahap dari penelitian pengembangan Training Kit Power Electronic untuk proses pembelajaran Praktikum Elektronika Daya mahasiswa Jurusan Teknik Elektro yaitu analisis pengujian validitas. Validitas Training Kit Power Electronic ini dibagi menjadi tiga aspek yaitu aspek desain, media/peralatan laboratorium, dan materi. Setiap aspek tersebut divalidiasi masing-masing oleh dua orang validator yang memiliki keahlian sesuai dengan aspek-aspek tersebut. Instrumen yang digunakan pada pengujian validitas ini adalah angket validitas yang telah melalui proses validasi instrumen sebelumnya. Analisis dilakukan dengan teknik analisis validitas Aiken's V. Kemudian diinterprestasikan dengan tabel interprestasi validitas pengembangan produk untuk mendapatkan kategori validitas. Hasil penelitian menunjukkan Training Kit Power Electronic yang dikembangkan valid pada semua aspek baik aspek desain, media/peralatan laboratorium, maupun materi. Aspek desain memperoleh nilai $V=0,89$ dengan kategori valid, aspek media/peralatan laboratorium memperoleh nilai $V=0,88$ yang berarti valid, dan aspek materi memperoleh nilai $V=0,93$ dengan kategori valid. Dengan demikian, dapat disimpulkan bahwa Training Kit Power Electronic yang dikembangkan untuk proses pembelajaran Praktikum Elektronika Daya mahasiswa Jurusan Teknik Elektro valid dalam aspek desain, media/peralatan laboratorium, dan materi.
\end{abstract}

\section{Kata kunci: Training Kit Power Electronic, Praktikum Elektronika Daya, Analisis Uji Validitas}

Abstract-This study discusses one of the stages of the research in the development of the Power Electronics Training Kits in the learning process of the Power Electronics Practicum for Electrical Engineering students, namely the validity test analysis. The validity of the Power Electronics Training Kits is divided into three aspects, namely design, media/laboratory equipment, and materials aspects. Each of these aspects was validated each by two validators who had expertise in these aspects. The instrument used in testing this validity was a validated questionnaire that had gone through the previous instrument validation process. The analysis was carried out using Aiken's V Analysis. Validity analysis results are interpreted with the product development validity interpretation table by Aiken's to obtain the validity category. The results showed the Training Kits is valid in all aspects both aspects of design, media/laboratory equipment, and materials. The design aspect gained a value of $V=0.89$ with a valid category, the media/laboratory equipment aspect gained a value of $V=0.88$ which means valid, and the material aspect gained a value of $V=0.94$ with a valid category. Thus, it can be concluded that the Power Electronics Training Kits developed for the learning process of the Power Electronics Practicum for Electrical Engineering students is valid in the aspects of design, media/laboratory equipment, and materials.

Keywords: Power Electronics Training Kits, Power Electronics Practicum, Validity Test

\section{Pendahuluan}

Media pembelajaran memiliki peran yang sangat penting dalam suatu pelaksanaan proses pembelajaran. Pemilihan dan penggunaan media pembelajaran yang baik merupakan salah satu faktor penentu keberhasilan pelaksanaan proses pembelajaran dalam upaya mengoptimalkan pencapaian tujuan pembelajaran (Arsyad, 2013; Yanto, 2019). Dalam proses pembelajaran praktikum terdapat beberapa jenis media yang dapat digunakan dengan karakteristik dan kelebihan masing-masing yang dalam memilihnya dibutuhkan penyesuaian dengan karakteristik materi dan proses pembelajaran yang akan diterapkan. Salah satu dari media 
pembelajaran yang dapat digunakan pada proses pembelajaran tersebut adalah Training Kit (Candra, Dewi, Yanto, \& Hastuti, 2020; Sardiman, 2008).

Training Kit adalah satu media pembelajaran praktikum berbentuk seperangkat alat, bahan termasuk alat ukur yang berguna untuk mensimulasikan suatu rangkaian atau percobaan tertentu dengan bentuk yang lebih praktis. Dengan bentuk yang lebih praktis sehingga mempermudah penggunaannya dalam proses pembelajaran. Penggunaan Training Kit harus benar-benar disesuaikan dengan karakteristik materi dan pelakasanan proses pembelajaran. $\mathrm{Ha}$ ini dikarenakan satu Training Kit tidak bisa digunakan untuk semua proses pembelajaran. Dengan demikian maka dalam memilih dan menetukan Training Kit yang akan digunakan dalam proses pembelajaran maka dibutuhkan suatu analis tentang karektesitik materi dan proses pembelajaran. Hal ini akan dapat dengan mudah dilakukan jika Training Kit yang akan digunakan merupakan hasil dari pengembangan sendiri yang disesuaikan dengan kebutuhan pada proses pembelajaran.

Praktikum Elektronika Daya merupakan salah satu proses pembelajaran praktikum mahasiswa Jurusan Teknik Elektro yang dalam pelaksanaan merupakan proses pembelajarna ekperimen di dalam laboratorium. Tujuan dari proses pembelajaran ini adalah menghasilkan mahasiswa yang mampu melakukan praktek dan menganalisis rangkaianrangkaian elektronika daya yang banyak diterapkan dan digunakan dalam kegiatan sehari hari dewasa ini. Seperti penyearah (rectifier), Inverter, dan penerapan lainya (Flåten, Bergna-Diaz, Sanchez, \& Tedeschi, 2017; Yang, Pian, \& Liu, 2019). Berdasarkan karakteristik materi dan proses pembelajaran praktikum elektronika daya, maka dibutuhkan suatu media pembelajaran praktek yang mampu mendukung pelaksanaan proses pembelajaran di laboratorium dengan baik sehingga mampu membantu pelaksanaan proses pembelajaran untuk mencapai tujuan pembelajaran yang optimal. Salah satu media pembelajarna yang dapat dijadikan alternatif pilihan untuk proses pembelajaran ini adalah Training Kit. Hal ini disebabkan oleh kebutuhan akan media pembelajaran praktikum yang sesuai dengan karakteristik materi dan proses pembelajaran praktikum elektronika daya (Yanto, Astrid, Hidayat, \& Islami, 2019; Yanto, Hidayat, \& Hamdani, 2018).

Pengembangan Training Kit ini perlu memperhatikan beberapa aspek penting dalam pelaksanaanya, agar produk yang dihasilkan benarbenar sesuai dengan karakteristik materi dan proses pembelajaran. Sehingga dengan demikian, Training Kit yang dikembangkan mampu menjadi media pembelajaran praktikum yang baik terutama dalam membantu tujuan pembelajaran secara maksimal (Sanaky, 2009; Yanto et al., 2018). Dengan mengadopsi langkah penelitian pengembangan Four- $D$ maka setidaknya terdapat 4 fase utama pengembangan Training Kit ini agar dapat digunakan dalam proses pembelajaran yaitu fase Define (Pendefenisian), Design (Perancangan), Develop (Pengembangan) dan Disseminate (Pengunaan/Penyebaran) (Heinich, 2005; Trianto, 2009). 4 fase tersebut dilaknakan untuk menjamin bahwa produk yang dikembangkan berupa Training Kit adalah produk yang valid, praktis, dan efektif untuk digunakan pada proses pembelajaan praktikum elektronika daya (Yanto et al., 2018; Yanto, Sukardi, \& Puyada, 2017).

Salah satu dari 4 fase pengembangan yang dilakukan adalah fase Pengembangan. Fase Pengembangan ini merupakan salah satu fase pokok dalam penelitian pengembanga yang terdiri dari tahap validasi, ujicoba produk, uji praktikalitaas dan efektifitas. Untuk memastikan produk yang dikembangkan telah benar dan sesuai dengan materi pembelajaran serta memastikan produk yang dihasilkan memenuhi kriteria sebagai media pembelajaran maka dibutukn pengujian validitas.

Pengujian validitas dilakukan setelah produk selesai di rancang dan dibuat yang berfungsi untuk memastikan bahwa produk yang dihasilkan layak untuk di uji coba pada proses pembelajaran praktikum elektronika daya. Oleh karena itu, maka dilakukan penelitian tentang analisis pengujian validitas Training Kit Power Elektronics yang dikembangkan untuk proses pembelajaran Praktikum Elektronika Daya mahasiswa Jurusan Teknik Elektro, Fakultas Teknik, di Universitas Negeri Padang. Tujuan dari penelitian ini adalah menguji dan menganalisis validitas Training Kit Power Electronics sebelum dapat diuji coba penggunaanya pada proses pembelajaran praktek elektronika daya.

Media Secara bahasa dapat diartikan sebagai alat perantara atau pengatar suatu pesan dari pemberi pesan kepada penerima pesan. Alat tersebut dapat berbentuk perangkat keras (hardware) maupun perangkat lunak (software) (Choi et al., 2018; Paratore, O’Brien, Jiménez, Salinas, \& Ly, 2016). Sedangkan, media pembelajaran adalah semua hal atau komponen yang ada di lingkungan seseorang yang dapat menjadi perantara untuk menyampaikan pesan-pesan pengetahuan atau pendidikan kepadanya, serta mempengaruhi dan merangsang seseorang tersebut untuk belajar. Komponen tersebut baik berupa perangkat keras (hardware) maupun perangkat lunak (software). Dengan sederhana media dapat didefenisikan bahwa kaitan media 
dengan pembelajaran adalah media sebagai suatu perantara atau pengantar pesan-pesan atau materi ajar dari guru kepada siswa (Arsyad, 2013; Yanto et al., 2017).

Media pembelajaran secara umum berfungsi untuk mempermudah penyampaian materi pembelajaran dari seorang pendidik ke peserta didik sehingga dapat membantu guru dan mempermudah pemahaman siswa dalam proses pembelajaran. Media pembelajaran yang baik akan dapat meningkatkan proses belajar siswa dalam proses pembelajaran yang pada gilirannya diharafkan mampu meningkatkan hasil belajar siswa. Penggunaan media Pembelajaran akan sangat membantu keefektifan proses pembelajaran dan penyampaian informasi (pesan dan isi pelajaran) pada saat itu. (Hobbs, Trevisan, Johansen, Dorny, \& Gabriël, 2019; Sardiman, 2008).

Media Secara bahasa dapat diartikan sebagai alat perantara atau pengatar suatu pesan dari pemberi pesan kepada penerima pesan. Alat tersebut dapat berbentuk perangkat keras (hardware) maupun perangkat lunak (software) (Choi et al., 2018; Paratore et al., 2016). Sedangkan, media pembelajaran adalah semua hal atau komponen yang ada di lingkungan seseorang yang dapat menjadi perantara untuk menyampaikan pesan-pesan pengetahuan atau pendidikan kepadanya, serta mempengaruhi dan merangsang seseorang tersebut untuk belajar. Komponen tersebut baik berupa perangkat keras (hardware) maupun perangkat lunak (software). Dengan sederhana media dapat didefenisikan bahwa kaitan media dengan pembelajaran adalah media sebagai suatu perantara atau pengantar pesan-pesan atau materi ajar dari guru kepada siswa (Arsyad, 2013; Yanto et al., 2017).

Media pembelajaran secara umum berfungsi untuk mempermudah penyampaian materi pembelajaran dari seorang pendidik ke peserta didik sehingga dapat membantu guru dan mempermudah pemahaman siswa dalam proses pembelajaran. Media pembelajaran yang baik akan dapat meningkatkan proses belajar siswa dalam proses pembelajaran yang pada gilirannya diharafkan mampu meningkatkan hasil belajar siswa. Penggunaan media Pembelajaran akan sangat membantu keefektifan proses pembelajaran dan penyampaian informasi (pesan dan isi pelajaran) pada saat itu. (Hobbs et al., 2019; Sardiman, 2008).

Training Kit merupakan salah satu jenis media pembelajaran untuk prose pembelajaran praktikum di laboratorium. Training Kit atau biasa juga disebut Trainer Kit atau Trainer merupakan seperangkat alat dan bahan yang dibutuhkan dalam proses pembelajarn praktikum yang diesain dan dibuat sedemikian rupa menjadi satu kesatuan yang utuh sehingga lebih praktis dalam penggunaanya (Arsyad, 2013; Singhato, Banjong, \& Charoonruk, 2017). Dengan adanya Training Kit ini maka proses pembelajaran praktikum akan berlangsung lebih praktis dan efisisen dalam penggunaan waktu pembelajaran.

Training Kit dalam proses pembelajaran praktikum biasanya digunakan untuk mensimulasikan rangkaian atau percobaan tertentu dengan tujuan membuktikan materi teoritis yang melibatkan aktifitas belajar peserta didik. Training Kit yang digunakan untuk setiap jenis proses pembelajaran juga memiliki perbedaan masingmasing sesuai dengan karakteristik materi dan proses pembelajaran yang diterapkan (Arsyad, 2013; Sardiman, 2008). Training Kit yang dikembangkan dalam penelitian ini adalah Training Kit yang digunakan untuk proses pembelajaran praktikum elektronika daya mahasiswa jurusan teknik elektro yang diberi nama Training Kit Power Electronics.

Training Kit Power Electronics merupakan seperangkat alat dan bahan praktikum elektronika daya yang didesain dan dibuat menjadi satu kesatuan utuh, peralatan ini dapat digunakan untuk membantu mensimulasikan rangkaian elektronika daya berdasarkan kebutuhan materi proses pembelajaran praktikum elektronika daya seperti, penyearah tak terkendali setengah gelombang 1 fasa dan 3 fasa, penyearah terkendali gelombang penuh 1 fasa dan 3 fasa, penyearah terkendali gelombang penuh 1 fasa dan 3 fasa, inverter 1 fasa dan 3 fasa, dan regulator tegangan (Candra et al., 2020; Yanto et al., 2019, 2018).

\section{METODE}

Pada penelitian ini pengujian validitas dilakukan oleh validator yang merupakan ahli pada bidang media pembelajaran dan materi pembelajaran elektronika daya. Validator akan memberikan penilaian validitas berdasarkan instrumen validitas yang diberikan. Terdapat tiga aspek validasi yaitu aspek desain/rancangan, aspek media/ peralatan laboratorium dan aspek materi pembelajaran. Setiap aspek masing-masing divalidasi oleh dua orang ahli.

\section{A. Instrumen Penelitian}

Intrumen penelitian yang digunakan adalah berupa lembar validasi produk yang dikembangkan berdasarkan aspek-aspek validitas yang diuji. Pada penelitian ini aspek validitas dibagi menjadi tiga yaitu aspek desain, aspek media, dan aspek materi. Aspek desain adalah aspek validasi yang berhubungan dengan kebenaran, kerapian dan kesesuaian desain produk dengan fungsi dari produk yang dikembangkan. Aspek media adalah aspek 
validasi yang berhubungan dengan pemenuhan fungsi dan kriteria sebagai media pembelajaran praktikum, termasuk didalamnya aspek standarisasi laboratorium serta penerapan prinsip kesehatan dan keselamatan kerja di dalam laboratorium. Sedangkan aspek materi adalah aspek validasi yang berhubungan dengan kebenaran dan kesesuaian Training Kit yang dikembangkan dengan materi pembelajaran dimana Training Kit ini akan diterapkan. Kisi-kisi instrumen validitas ini disajikan pada tabel 1 .

Tabel 1. Kisi- Kisi Instrumen Validitas

\begin{tabular}{|c|c|c|}
\hline No. & $\begin{array}{c}\text { Aspek } \\
\text { Validasi }\end{array}$ & Indikator \\
\hline 1. & Desain & $\begin{array}{l}\text { a. Berbentuk Praktis } \\
\text { b. Mengutamakan Prinsip } \\
\text { Kesehatan dan Keselamatan } \\
\text { Kerja } \\
\text { c. Unsur Kemudahan Pengunaan } \\
\text { d. Tata Letak dan Jumlah } \\
\text { Komponen sesuai dengan } \\
\text { Kebutuhan Materi Pembelajaran }\end{array}$ \\
\hline 2. & $\begin{array}{l}\text { Aspek } \\
\text { Media }\end{array}$ & 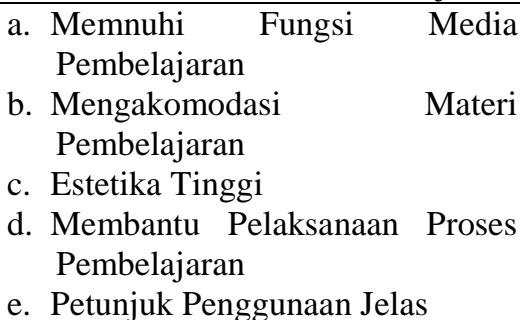 \\
\hline 3. & $\begin{array}{l}\text { Aspek } \\
\text { Materi }\end{array}$ & $\begin{array}{l}\text { a. Kesesuaian dengan Materi } \\
\text { Pembelajaran. } \\
\text { b. Kesesuaian dengan kurikulum } \\
\text { dan SAP pembelajaran } \\
\text { c. Mengkomodasi proses } \\
\text { pembelajaran secara keseluruhan }\end{array}$ \\
\hline
\end{tabular}

Berdasarkan tabel 1 dapat diketahui bahwa kisi-kisi intrumen validitas berdasarkan tiga aspek utama validasi terdiri dari 12 sub aspek. Kisi-kisi ini lah yang menjadi dasar penyusunan instrumen. Setelah melalui proses validasi intrumen maka didapatkan instrumen validitas aspek desain terdiri dari 14 item validasi, aspek media terdiri dari 12 item validasi, dan untuk aspek materi terdiri dari 12 item validasi. Setiap item validasi diberi pilihan penilaian, skala penilaian yang digunakan adalah skala likert.

\section{B. Teknik Analisis Data}

Data hasil pengisian lembar validitas oleh validator dijadikan acuan dalam melakukan analisis data. Data validitas dianalisis dengan teknik analisis validitas Aiken's V (Arikunto, 2008; Sugiyono, 2018). Adapun rumus Aiken's V yang digunakan pada penelitian ini adalah sebagai berikut.

$$
\mathrm{V}=\sum \mathrm{s} /[\mathrm{n}(\mathrm{c}-1)]
$$

Pengujian analisis ini dilakukan pada masingmasing aspek. Hasil analisis dengan Aiken's V untuk masing-masing aspek validasi kemudian diinterpretasikan dengan tabel interprestasi nilai Aiken's V untuk memperoleh kategori validitas yang diuji (Arikunto, 2008; Candra et al., 2020; Sugiyono, 2018).

\section{HASIL}

Hasil Data validitas yang didapatkan dari lembar validasi yang diisi oleh validator untuk masing-masing aspek kemudian dianalisis dengan menggunakan teknik analisis data yang tealah ditentukan. Pengujian ini dilakukan pada masingmasign aspek secara tepisah.

\section{A. Validasi Desain}

Validasi desain dilakukan oleh dua orang validator ahli desain. Data penilaian validasi diperoleh setelah validator memberikan peneilian melalui pengisian pada intrumen validitas yang telah disediakan. Pengisian isntrumen ini dilakukan validator setelah mengamati dan mencoba langsung Training Kit yang dikembangkan. Hasil validasi ini kemudian dianalisis menggunakan analisis Aiken'S V. Hasil analisis disajikan pada tabel 2.

Tabel 2. Hasil Analisis Validasi Desain

\begin{tabular}{|c|c|c|c|c|c|c|c|}
\hline \multirow{3}{*}{ Item } & \multirow{2}{*}{\multicolumn{2}{|c|}{$\begin{array}{c}\text { Validator } \\
1 \\
\end{array}$}} & \multirow{2}{*}{\multicolumn{2}{|c|}{$\begin{array}{c}\text { Validator } \\
2 \\
\end{array}$}} & \multirow{3}{*}{$\Sigma \mathrm{S}$} & \multirow{3}{*}{ V } & \multirow{3}{*}{ Kategor } \\
\hline & & & & & & & \\
\hline & Skor & $\mathrm{S}$ & Skor & $\mathrm{S}$ & & & \\
\hline 1 & 5 & 4 & 4 & 3 & 7 & 0,88 & Valid \\
\hline 2 & 5 & 4 & 5 & 4 & 8 & 1,00 & Valid \\
\hline 3 & 4 & 3 & 4 & 3 & 6 & 0,75 & Valid \\
\hline 4 & 4 & 3 & 4 & 3 & 6 & 0,75 & Valid \\
\hline 5 & 5 & 4 & 4 & 3 & 7 & 0,88 & Valid \\
\hline 6 & 5 & 4 & 4 & 3 & 7 & 0,88 & Valid \\
\hline 7 & 5 & 4 & 5 & 4 & 8 & 1,00 & Valid \\
\hline 8 & 5 & 4 & 5 & 4 & 8 & 1,00 & Valid \\
\hline 9 & 5 & 4 & 4 & 3 & 7 & 0,88 & Valid \\
\hline 10 & 4 & 3 & 4 & 3 & 6 & 0,75 & Valid \\
\hline 11 & 5 & 4 & 5 & 4 & 8 & 1,00 & Valid \\
\hline 12 & 5 & 4 & 4 & 3 & 7 & 0,88 & Valid \\
\hline 13 & 4 & 3 & 4 & 3 & 6 & 0,75 & Valid \\
\hline 14 & 5 & 4 & 5 & 4 & 8 & 1,00 & Valid \\
\hline Total & 66 & 52 & 61 & 47 & 99 & 12,4 & - \\
\hline $\begin{array}{l}\text { Rata- } \\
\text { rata }\end{array}$ & 4,7 & 3,7 & 4,4 & 3,4 & 7,1 & 0,89 & Valid \\
\hline
\end{tabular}

Berdasarkan hasil analisis pada tabel 2 dapat diketahui bahwa rata-rata nilai $\mathrm{V}$ yang didapatkan adalah 0,89 dengan kategori valid, selain itu dari 14 item yang divalidasi berdasarkan instrumen validitas semua item memperoleh nilai $\mathrm{V} \geq 0,75$ yang berarti 
valid. Dengan demikian maka Training Kit Power Elctronics yang dikembangkan valid pada aspek desain

\section{B. Validasi Media}

Validasi Media dilakukan oleh dua orang validator yang ahli dalam bidang Media pembelajaran dan Peralatan Laboratorium. Data penilaian validasi diperoleh setelah validator memberikan peneilian melalui pengisian pada intrumen validitas yang telah disediakan. Pengisian isntrumen ini dilakukan validator setelah mengamati dan mencoba langsung Training Kit yang dikembangkan. Hasil validasi ini kemudian dianalisis menggunakan analisis Aiken'S V. Hasil analisis disajikan pada tabel 3 .

Tabel 3. Hasil Analisis Validasi Media

\begin{tabular}{cccccccc}
\hline & \multicolumn{9}{c}{ Validator } & \multicolumn{2}{c}{ Validator } \\
Item & \multicolumn{2}{c}{1} & \multicolumn{2}{c}{2} & $\Sigma \mathrm{S}$ & $\mathrm{V}$ & Kategori \\
\cline { 2 - 5 } & Skor & $\mathrm{S}$ & Skor & $\mathrm{S}$ & & & \\
\hline 1 & 5 & 4 & 5 & 4 & 8 & 1,00 & Valid \\
2 & 5 & 4 & 5 & 4 & 8 & 1,00 & Valid \\
3 & 5 & 4 & 5 & 4 & 8 & 1,00 & Valid \\
4 & 4 & 3 & 4 & 3 & 6 & 0,75 & Valid \\
5 & 5 & 4 & 4 & 3 & 7 & 0,88 & Valid \\
6 & 4 & 3 & 4 & 3 & 6 & 0,75 & Valid \\
7 & 4 & 3 & 5 & 4 & 7 & 0,88 & Valid \\
8 & 5 & 4 & 4 & 3 & 7 & 0,88 & Valid \\
9 & 4 & 3 & 4 & 3 & 6 & 0,75 & Valid \\
10 & 4 & 3 & 4 & 3 & 6 & 0,75 & Valid \\
11 & 4 & 3 & 5 & 4 & 7 & 0,88 & Valid \\
12 & 5 & 4 & 5 & 4 & 8 & 1,00 & Valid \\
\hline Total & 54 & 42 & 54 & 42 & 84 & 10,52 & - \\
\hline Rata- & 4,5 & 3,5 & 4,5 & 3,5 & 7 & 0,88 & Valid \\
rata & 4,5 & & & & & \\
\hline
\end{tabular}

Berdasarkan hasil analisis pada tabel 3 dapat diketahui bahwa rata-rata nilai $\mathrm{V}$ yang didapatkan adalah 0,88 dengan kategori valid. Selain itu, dari 12 item yang divalidasi berdasarkan instrumen validitas semua item memperoleh nilai $\mathrm{V} \geq 0,75$ yang berarti valid. Dengan demikian maka Training Kit Power Elctronics yang dikembangkan valid pada aspek media dan peralatan laboratorium.

\section{Validasi Materi}

Validasi Materi dilakukan oleh dua orang validator yang ahli materi pembelajaran yaitu materi pembelajaran Elektronika Daya untuk tingkat Mahasiswa Jurusan Teknik Elektro. Data penilaian validasi diperoleh setelah validator memberikan peneilian melalui pengisian pada intrumen validitas yang telah disediakan. Pengisian isntrumen ini dilakukan validator setelah mengamati dan mencoba langsung Training Kit yang dikembangkan. Hasil validasi ini kemudian dianalisis menggunakan analisis Aiken'S V. Hasil analisis disajikan pada tabel 4.

Tabel 4. Hasil Analisis Validasi Materi

\begin{tabular}{|c|c|c|c|c|c|c|c|}
\hline \multirow{3}{*}{ Item } & \multirow{2}{*}{\multicolumn{2}{|c|}{$\begin{array}{c}\text { Validator } \\
1\end{array}$}} & \multirow{2}{*}{\multicolumn{2}{|c|}{$\begin{array}{c}\text { Validator } \\
2\end{array}$}} & \multirow{3}{*}{$\Sigma \mathrm{S}$} & \multirow{3}{*}{ V } & \multirow{3}{*}{ Kategori } \\
\hline & & & & & & & \\
\hline & Skor & $\mathrm{S}$ & Skor & $\mathrm{S}$ & & & \\
\hline 1 & 5 & 4 & 5 & 4 & 8 & 1,00 & Valid \\
\hline 2 & 5 & 4 & 4 & 3 & 7 & 0,88 & Valid \\
\hline 3 & 5 & 4 & 5 & 4 & 8 & 1,00 & Valid \\
\hline 4 & 4 & 3 & 4 & 3 & 6 & 0,75 & Valid \\
\hline 5 & 4 & 3 & 5 & 4 & 7 & 0,88 & Valid \\
\hline 6 & 5 & 4 & 5 & 4 & 8 & 1,00 & Valid \\
\hline 7 & 5 & 4 & 5 & 4 & 8 & 1,00 & Valid \\
\hline 8 & 4 & 3 & 5 & 4 & 7 & 0,88 & Valid \\
\hline 9 & 4 & 3 & 4 & 3 & 6 & 0,75 & Valid \\
\hline 10 & 5 & 4 & 5 & 4 & 8 & 1,00 & Valid \\
\hline 11 & 3 & 4 & 4 & 3 & 7 & 0,88 & Valid \\
\hline 12 & 5 & 4 & 5 & 4 & 8 & 1,00 & Valid \\
\hline 13 & 5 & 4 & 5 & 4 & 8 & 1,00 & Valid \\
\hline 14 & 5 & 4 & 5 & 4 & 8 & 1,00 & Valid \\
\hline Total & 64 & 52 & 66 & 52 & 104 & 13,02 & - \\
\hline $\begin{array}{c}\text { Rata- } \\
\text { rata }\end{array}$ & 4,6 & 3,6 & 4,7 & 3,5 & 3,7 & 0,93 & Valid \\
\hline
\end{tabular}

Berdasarkan hasil analisis pada tabel 4 dapat diketahui bahwa rata-rata nilai $\mathrm{V}$ yang didapatkan adalah 0,93 dengan kategori valid. Selain itu, dari 14 item yang divalidasi berdasarkan instrumen validitas semua item memperoleh nilai $\mathrm{V} \geq 0,75$ yang berarti valid. Dengan demikian maka Training Kit Power Elctronics yang dikembangkan valid pada aspek materi pembelajaran.

Hasil analisis validitas dari ketiga aspek validasi dapat diketahui bahwa Training Kit Power Elctronics yang dikembangkan untuk proses pembelajaran praktikum elektronika daya dinyatakan valid pada aspek desain, media, dan juga materi pembelajaran. Hasil penilaian rata-rata validasi dari ketiga aspek validasi tersebut disajikan pada gambar 1. 


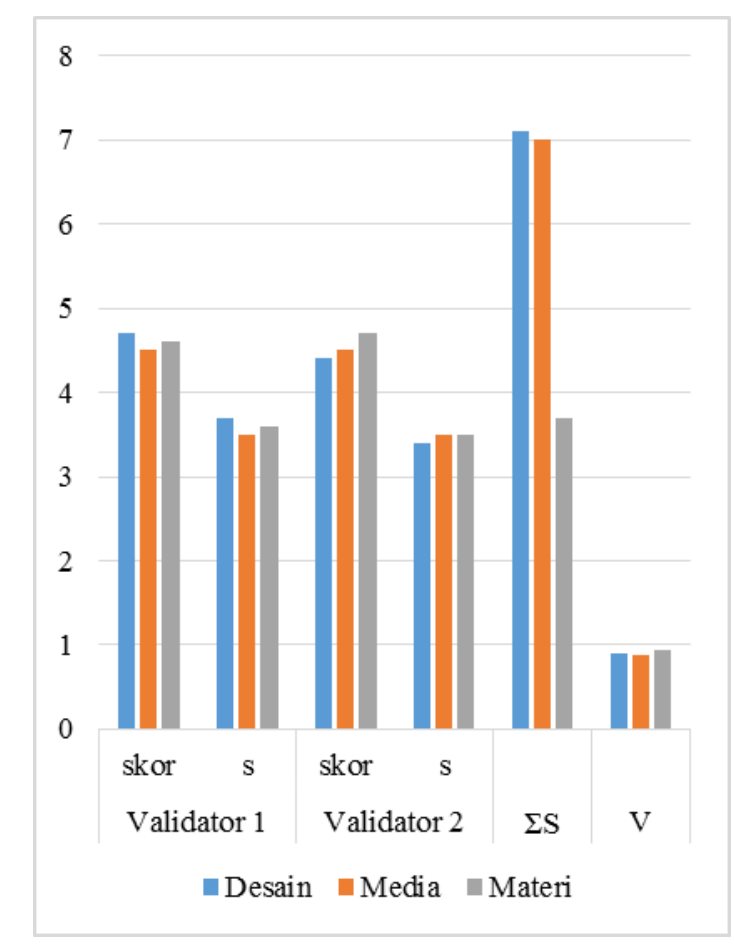

Gambar 1. Grafik Analisis Validitas dari Tiga Aspek Validasi

\section{Pembahasan}

Training Kit Power Electronics dibangun dan dikembangkan berdasarkan analisis kebutuhan pada mahasiswa dan materi pembelajaran pada proses pembelajaran Praktikum Elektronika Daya. Proses pengembangan Training Kit Power Electronics harus telah melewati beberapa tahap pengujian sebagai persyaratan sebelum produk dapat diterapkan pada proses pembelajaran (Candra et al., 2020; Sukardi, Puyada, Wulansari, \& Yanto, 2017). Salah satu yang terpenting dalam pengujian ini adalah tahap pengujian validitas yang merupakan penilian tingkat kebenaran yang menjadi acuan kelayakan perangkat trainer ini dapat diterapkan dalam proses pembelajaran (Hobbs et al., 2019; Yanto, 2019). Hal ini dikarenakan sebelum suatu produk dapat diujicobakan maka harus dilakukan pengujian validasi oleh ahli yang sesuai dengan aspek yang diavalidasi, kegiatan validasi ini dapat dilakukan secara berulang-ulang sehingga didapakan hasil bahwa produk tersebut telah valid dan dapat diujicobakan.

Tahap uji validitas menunjukkan bahwa media Training Kit Power Electronics telah valid berdasarkan tiga aspek yang divalidasi. Tiga aspek tersebut adalah aspek desain, media, dan materi. Dengan hasil validitas dari ketiga aspek tersebut dapat dijadikan acuan dalam pengambilan keputusan bahwa Training Kit Power Electronics telah valid dan memnuhi kriteria sebagai media pembelajaran praktikum untuk proses pembelajaran praktikum Elektronika Daya mahasiwa Jurusan Teknik Elektro. Selanjutnya berdasarkan penelitian-penelitian yang dilakukan oleh para peneliti sebelumnya menyatakan bahwa apbila suatu produk telah dinyatakan valid maka telah bisa dilakukan ujicoba lapangan untuk mendapatkan data-data pengujian lain sebelum produk tersebut dapat digunakan dan diterapkan secara reguler (Billett, 2004; Hamdani, Yanto, \& Maulana, 2019; Singhato et al., 2017; Sukardi et al., 2017; Yanto et al., 2019, 2018).

\section{KESIMPULAN}

Hasil kegiatan pengujian dan analisis terhadap hasil pengujian validitas pada Training Kit Power Electronics dapat disimpulkan bahwa Training Kit Power Electronics telah valid secara keseluruhan. Keputusan valid didapatkan berdasarkan validitas dari tiga aspek utama validasi yaitu aspek desai media, dan materi. Dengan demikian maka Training Kit Power Electronics yang dikembangkan pada proses pembelajaran Praktikum Elektronika Daya untuk mahasiswa Jurusan Teknik Elektro dinyatakn valid secara desain, media, dan materi pembelajarn Elektronika Daya.

\section{DAfTAR PUStaka}

Arikunto, S. (2008). Dasar-Dasar Evaluasi Pendidikan (Edisi Revisi). Jakarta: Bumi Aksara.

Arsyad, A. (2013). Media Pembelajaran. Jakarta: Rajawali Press.

Billett, S. (2004). Workplace participatory practices: Conceptualising workplaces as learning environments. Journal of Workplace Learning, 16(6), $312-324$ https://doi.org/10.1108/13665620410550295

Candra, O., Dewi, C., Yanto, D. T. P., \& Hastuti, H. (2020). The Implementation of Power Electronics Training to Enhance Student Learning Activities in the Power Electronics Learning Process. International Journal of Innovation, Creativity and Change, 11(4), 362-373. Retrieved from https://www.ijicc.net/index.php/ijicceditions/2020/155-vol-11-iss-4

Choi, J. H., Mendelsohn, A. L., Weisleder, A., Cates, C. B., Canfield, C., Seery, A., ... Tomopoulos, S. (2018). Real-World Usage of Educational Media Does Not Promote Parent-Child Cognitive Stimulation Activities. Academic Pediatrics, 18(2), 172-178.

https://doi.org/10.1016/j.acap.2017.04.020

Flåten, I., Bergna-Diaz, G., Sanchez, S., \& Tedeschi, E. (2017). Control of HVDC systems based on diode rectifier for offshore wind farm applications. 
Energy Procedia, 137, 406-413. https://doi.org/10.1016/j.egypro.2017.10.365

Hamdani, H., Yanto, D. T. P., \& Maulana, R. (2019). Validitas Modul Tutorial Gambar Teknik dan Listrik dengan Autocad. INVOTEK: Jurnal Inovasi Vokasional Dan Teknologi, 19(2), 83-92. https://doi.org/10.24036/invotek.v19i2.491

Heinich. (2005). Instructional Technology and Media for Learning. New Jersey, Columbus, Ohio: New Jersey, Columbus, Ohio: Pearson Merrill Prentice Hall. Upper Saddle River.

Hobbs, E. C., Trevisan, C., Johansen, M. V., Dorny, P., \& Gabriël, S. (2019). Value of Electronic Educational Media in Combatting Parasitic Diseases. Trends in Parasitology, 35(3), 173-176. https://doi.org/10.1016/j.pt.2018.10.001

Paratore, J. R., O’Brien, L. M., Jiménez, L., Salinas, A., \& Ly, C. (2016). Engaging preservice teachers in integrated study and use of educational media and technology in teaching reading. Teaching and Teacher Education, 59, 247-260. https://doi.org/10.1016/j.tate.2016.06.003

Sanaky, A. . H. (2009). Media Pembelajaran. Yogyakarta: Safiria Insania Press.

Sardiman, A. (2008). Media Pembelajaran (Pengertian Pengembangan Pemanfaatan). Jakarta: Rajawali Press.

Singhato, A., Banjong, O., \& Charoonruk, G. (2017). Effectiveness and acceptance of the developed educational media on the application of a Thai ethnic snack, Thong Pub, with calcium fortification. Journal of Ethnic Foods, 4(1), 58-63. https://doi.org/10.1016/j.jef.2017.02.007

Sugiyono. (2018). Metode Penelitian Kuantitatif, Kualitatif dan $R \& D$. Bandung: Alfabeta.
Sukardi, S., Puyada, D., Wulansari, R. E., \& Yanto, D. T. P. (2017). The validity of interactive instructional media on electrical circuits at vocational high school and technology. The 2nd INCOTEPD, 2017, 21-22.

Trianto, T. (2009). Mendesain Model Pembelajaran Inovatif Progresif. Jakarta: Kencana.

Yang, Y., Pian, Y., \& Liu, Q. (2019). Design of energy harvester using rotating motion rectifier and its application on bicycle. Energy, 179, 222-231. https://doi.org/10.1016/j.energy.2019.05.036

Yanto, D. T. P. (2019). Praktikalitas Media Pembelajaran Interaktif pada Proses Pembelajaran Rangkaian Listrik. INVOTEK: Jurnal Inovasi Vokasional Dan Teknologi, 19(1), 75-82. https://doi.org/10.24036/invotek.v19i1.409

Yanto, D. T. P., Astrid, E., Hidayat, R., \& Islami, S. (2019). Analisis Uji Kelayakan Trainer Kit Elektronika Daya : 3 Phase Half-Wave and FullWave Uncontrolled Rectifier. Jurnal Teknik Elektro Dan Vokasional, 5(1.1), 121-125.

Yanto, D. T. P., Hidayat, R., \& Hamdani, H. (2018). Rancang Bangun Trainer Elektronika Daya : Controlled and Uncontolled Rectifier. Prosiding Seminar Nasional Hasil Penelitian 2018 POLITEKNIK Ujung Pandang, 2018, 83-88. Retrieved from http://jurnal.poliupg.ac.id/index.php/snp/article/vie w/771

Yanto, D. T. P., Sukardi, S., \& Puyada, D. (2017). Effectiveness of Interactive Instructional Media on Electrical Circuits Course : The Effects on Students Cognitive Abilities. Proceedings of $4 \mathrm{rd}$ International Conference On Technical And Vocational Education And Training, 2017, 75-80. 